\title{
The Ethical Implications of Evolutionary Theory
}

ABSTRACT: This essay is primarily concerned with important arguments involved in the debate about the relationship between evolution and morality. Though the paper holds that it is plausible that certain natural traits would have evolved into human moral sentiments, it argues that evolutionary theory canno tell us how to be good people or why moral sentiments ought to take priority over immoral sentiments. Evolutionary theory is in this way an incomplete moral theory, analyzing how humans and human morality evolved through natural selection can uncover implications of evolutionary theory, which have a strong impact on a theory of morality.

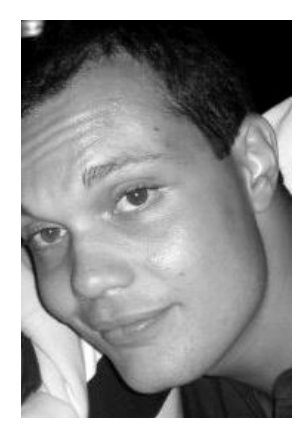

Marc Anthony Parker is a senior at Birmingham-Southern College in Birmingham, Alabama. Marc is a philosophy major with particular interests in pragmatism, environmental ethics, and postmodernism. $\mathrm{He}$ also has a great interest in Western philosophy in general. Outside of philosophy, his interests include religious studies, jazz, traveling, and knitting. Very recently, Marc completed a short documentary set in the Aran Islands off the western coast of Ireland. After graduation his plans are to take a road trip through Canada and to apply in the fall to graduate programs in philosophy.

$\mathrm{F}$

or decades, the issue of evolution's impact on ethical theories had been understandably shelved because the arguments had become deadlocked and other, more pressing issues emerged. However, now with major advances in biology, especially sociobiology and evolutionary biology, it has been brought back out and examined with renewed vigor. Also, because Darwin's theory makes up such a large part of the way most of mak view our species and the word, evost of us view our species and the world, evolution and ethics surly desves a second. To introduce the basics of evolutionary moral theory, we read from William F. Quillian, Jr., this:

The contention of Evolutionary Naturalism is that by the application of the theory of evolution to the investigation of moral phenomena Ethics can be placed for the first time upon a scientific basis. It is supposed that moral sentiments, customs and judgments have been gradually developed over a long period of time by that same process of natural selection which has determined the development of the present structure of animals, including man, from some earlier form. 
This statement generally describes the central Wiology cannot describe at the moment. theme of evolutionary ethics from Darwin This is why evolutionary ethics does not attemp through the present. Richard D. Alexander, a more recent evolutionary naturalist, has written that "it is necessary to understand thelife interests - therefore the life patterns - of humans as outcomes of an evolution guided principally by outcomes of an evolution guided principally by
natural selection," natural selection," ${ }^{2}$ and that by "understanding the evolutionary significance of the human
organism, and the nature of individuality of it organism, and the nature of individuality of its evolved interests, we may derive useful insight into human concerns about morality." 3 What follows now is an attempt to identify some of these insights, and I will put forth three specific ones - the need for adaptability, the importance of natural motives, and the body as a compas. Before that, however, there will be an exposition of what is involved in evolutionary ethics, the traditional debate around it, and my perceived limitations of the position. First it is important to make clear that evolutionary ethicists do not attempt to reduce human nature to biology alone. In an essay on the subject, Matthew $\mathrm{H}$. Nitecki does not cite, but he mentions C. G. Hempel's asertion from Philosophy of Natural Henpel's assotion Science that biology is not easily reducible to chemistry and physics. He says, "[f]or example you may resolve penicillin to a chemical
equation, but not as a substance produced by equation, but not as a substance produced by a living fungus Penicillium notatum." Nitecki
argues that it is even more difficult to reduce morality to biology. Morality never involves the same circumstances, so its components are things such as intentions, beliefs, and wants to reduce morality simply to genes.

Genes do not independently cause us to be moral. We are not, for instance, genetically coded to refrain from lying. Environment is asoo as much of a force upon our behavior as our genetic makeup. Alexander explains the way in which forms and functions can be effectively derived from genes:

No trait of an organism is maximized in its own particular function because all traits are part of of inclusive fitness maximizing remains as the s as the perpetuat combined effect of natural selection on the organism. Evolutionary compromises within the evolving organism as a result of conflicts among the "idealizing" of different functions are parliaments not so much in the sense of conflicting interests as in the sense of coordinations of extremely complex programs of effort (and possibly of differences in information among agreeing parties - or parts). ${ }^{5}$

The genes themselves are not in a vacuum within us. They must compromise and are ever independent.

The mechanisms for behavior are of these kinds of derived functions. Alexander further points out that "mechanisms evolve which tend to yield particular behaviors in particular environments." Genes encode traits, traits produce mechanisms by "cooperative a compromise in which the singular function

2. Richard D. Alexander, "Biological Considerations in the Analysis of Morality," in Evolutionary Ethics, ed. Matthew H. \& Doris V. Ni 2. Richard D. Alexander, "Biological Considerations in the Anal
tecki (Albany: State University of New York Press, 1993): 178.

3. Alexander, "Biological Considerations": 181.

4. Matthew H. Nitecki, "Problematic Worldviews of Evolutionary Ethics," in Evolutionary Ethics, ed. Matthew H. \& Doris V. Nitecki (Al-

bany: Stat University of New York Press, 1993): 22-23.
5. Alexander, "Biological Considerations": 170.

competition," and mechanisms tend to cause certain behaviors in certain conditions. There are so many internal and external factors playing into our behavior that the whole system is incredibly complex and still quite a mystery. It also implies that any one function from a set of traits is still under the control of the organism as a whole, so free will is not necessarily lost. ${ }^{6}$ Gene reduction and determinism for moral behavior and behavior, in general, are not comavior and behavior, in general, are not of behavioral mechanisms.

There are many objections, however, to
to There are many objections, however, to
elution's relevance to ethics. Those objections begin with Thomas H. Huxley during his famous Romanes Lecture in 1893, and most criticisms since then have stemmed from Huxley's arguments. Simply stated, it is that the "cosmic process," as he calls natural selection on a grand scale, the process by which nature develops and undergoes substantial changes, is one of constant struggle and battling, and in contrast, the way of humans is of tolerance and comfort.7 For Huxley, human society, made possible by morality, is a matter of artifice - not nature. He tells a story about a gardener as a striking metaphor for this. The gardener must constantly battle nature to continue cultivating his vegetales or flower, which represents those things which are good for him and those around him, uprooting weeds hat would normally be there, keeping away crows, and the like. He hoes, fertilizes, builds a fence, and can never let up or else his garden will become over grown by the types of things that were there before. What Huxley means by all of this is that human morality stands in

mplete opposition to the rest of nature, an thinks, therefore, that we cannot improve it from knowing the evolutionary process, which is hherently amoral or even immoral.

John Dewey's essay, "Evolution and Ethics," is largely a response to this lecture by Huxley. Dewey's underlying idea is that human morality does not contradict nature, or even another part of nature, but that it expands the possibilities of nature. For Dewey, nothing ever battles nature, but, instead, nature sculpts and fiddles with itself, even sometimes by means of human artistic endeavor. Nature is all-encompassing. He takes issue with Huxley's interpretation of the garden and the gardener. To Dewey, the gardener is actually a component of nature, a natural entity, modifying other components in a certain way that results in what we call a garden. oeds came from an says that he gardenor will place in nature. He for the amount of sun and water that reach the area, but that these things still "fall within the wont and use of nature as a whole." Dewey admits that, yes, the gardener must keep up with the forces trying to break down his or her work. It is a strugole. The gle, though, is not with the whole cosmos, but with his current conditions. This is where Huxley really misapplies the analogy. The ability to grow plants truly is an adaptation to conditions. To maintain the metaphor, then, is to say that morality is an adaptation to conditions. growing a garden conflicts with nature then would not know how to argue that bees are not also battling nature. They build a hive for 
insulation, protection, and convenience, and Natural selection might tell us that such a they run a honey factory inside it. Dewey says teleology is useful for our species' survival that humans do not contend against the whole under the circumstances in which it came about, of nature but that they "[read] the possibilities of but it does not tell us what it actually is. I think a part through its place in the whole." He goes Alexander comes closest to filling the hole with hire for good intervene, not as opposing forces but as making reputation, which better enables humans to this connection [between a part and the whole]." ${ }^{8}$ achieve other ends. This is considered indirect A part of Huxley's arguments survives, reciprocity because the subject gains long though. This can be found in his statement that term benefits from his or her good deeds, but "evolution may teach us how the good and the these actions would not necessarily give any evil tendencies of man may have come about; immediate and direct reward. Good reputation but, in itself, it is incompetent to furnish any requires consistently doing good things, which better reason why what we call good is preferable requires acting without hesitation within certain to what we call evil than we had before" $" 9$ I think conventions agreed upon by the members that Huxley is mistaken in completely dismissing of society. It then becomes a habit, and that any connection between moral inquiry and explains why we do what is "right" even when evolution, but I think that he rightly recognizes no one is looking. ${ }^{11}$

that evolutionary theory is incapable of providing There are significant problems with such

bast

Larry Arnhart's evolutionary account of important role that It neglects the extremely morality in Darwinian Natural Right makes clear lives and how it can be the primary motivating that while "the evolutionary process does not factor. Also, it seems to imply that if we were to serve goals, the organisms emerging from that admire someone who is martyred for the good process do. Darwin's biology does not deny or the right - rather, it reaffirms - the immanent teleology Sometimes doing the right thing damages our displayed in the striving of each living being reputation and situation for reciprocity. George to fulfill its specific ends (Lennox 1992, 1993)." Herbert Mead stated in a lecture that a man However, while it may affirm the teleology, sometimes "has to fly in the face of the whole it does not tell what the teleological end is. community in preserving [his] self-respect," Arnhart uses Aristotelian eudaimonia to fill in although "he does it from the point of view of the space, but that description of human ends what he considers a higher and better society cannot be derived from evolutionary theory. ${ }^{10}$ than that which exists. ${ }^{12}$ If this is true, then it

8. Dewey, John, “Evolution and Ethics," in Evolutionary Ethics, ed. Matthew H. \& Doris V. Nitecki (Albany: State University of New York Press, 1993): 98.

9. Huxley, "Evolution and Ethics": 66.
10. Larry Arnhart, Darwinian Natural Right: The Biological Ethics of Human Nature, (Albany: State University of New York Press, 1998): 245 .

11. Alexander, "Biological Considerations": 184.
12. George Herbert Mead, Mind, Self, and Society, (Chicago: The University of Chicago Press, 1934): 389. seems highly improbable to explain community concern with only direct and indirect forms of reciprocity as conceived purely on the basis of evolutionary theory.

Evolutionary theory can tell us that all humans are moral creatures, but it cannot tell us why we ought to do anything we say that we why we ought to do anytheg we say that we ought to do. It may demonstrate that we will surely be altruistic sometimes. It tells us that if we are not ever altruistic then cooperation breaks down and our chances of getting what we want and even living a long time greatly decrease. However, reading The Origin of Species cannot help someone decide whether or not to be honest when the truth would hurt someone's feelings. Evolutionary theory cannot tell someone how to be a "just person," how to reach eudaimonia, or how to be an "over man." No great prophet of history could have learned how to liberate or

of history could have
bring justice from it.

However, even though we cannot derive a moral theory from evolutionary theory, that does not mean we cannot learn anything at all about morality from evolution. As mentioned earlier, ethics has not been the same since Darwin. To begin to talk about useful connections between evolution and ethics, I turn to Michael Ruse's essay, "The New Evolutionary Ethics." In this excerpt, Ruse gives the starting point for exploring ethical implications of evolution:

[D]espite an evolutionary process, centering on a struggle for existence, organisms are not necessarily perpetually at conflict with weapons of attack and defence. In particular, cooperation can be a good biological strategy. We know also that humans are organisms which have preeminently taken this route of cooperation and working together. Further, there is good reason to think that a majo way in which humans cooperate together is by having an ethical sense. Humans believe that they should work together, and so - with obvious qualifications - they do so. ${ }^{13}$

Keeping this beginning in mind, the next task is to explore the implications it has upon our ethical lives. There may be more, but in this essay I will examine three. The first is that the proces of natural selection shows us the importance of change. Natural selection demonstrates that if anything is to survive, then it must be adapted to present conditions. The traits of complex to prentex a par to ads to changes in the enviromm its own lifetine are precious for survival and reproduction. This ability for a single organism to adapt within its lifetime to constantly changing circumstances matters for the entire species. This is important for ethics because if our traditions, institutions, and even our having an outlook on life are to survive then they must also adapt. Otherwise the natural selection will end the conditions do mean the end for an inst but it is usully me be ficisl fon insturon, ber it is usully me beneficial for an institution or tradition to adapt so that society might retain its essential wisdom than for that institution to simply die and that benefit become lost for a time. Since adaptation depends on constantly changing circumstances, when we consciously do this with ourselves and with our societies components by, as Dewey says, "empirical determination 13. Michael Ruse, “The New Evolutionary Ethics," in Evolutionary Ethics, ed. Matthew H. \& Doris V. Nitecki (Albany:
Stat University of New York Press, 1993): 152. 
not...a priori theorizing," which rules out some unwavering, blind idealism. ${ }^{14}$

he "natural constitution of desires and powers [of humans]... that might be either expressed or Evolutionary theory's second contribution to frustrated by such a custom". Arnhart says that ethics is demonstrating the import of our natural the only way to prudently reform practices like motives. Evolutionary theory tells us that we this is to understand the social conditions that have natural motives, it is good for us to foll it is good for us to follow then. These natural societies in which fent motives are things such as desires, but they are adopted are ones with high social stratification, more than that. They are anything that comes and in those societies, there is usually a limited to us by our human nature and that provokes us number of men who control the most resources. to act. Hunger, sympathy, empathy, narcissism, Hence, women are forced into a position of sexual desire, and fairness are a few examples. competition for high status males, and this often Evolutionary theory's problem is that it cannot includes showing signs of fidelity, such as female tell us which ones to follow when they conflict. circumcision. Arnhart suggests that males in the One might say that the guidance of reason is the society accept the practicebecause they naturally en in their family motive(s) are best and bare reason is not a motive. are in fact thir ofspring, assurance given when However, we also cannot justify the unnecessary they are confident of their wives' fidelity. ${ }^{1}$ denial of any of our motives, and not just our Reform to eliminate female circumcision and social, ethical motives, either. There have been other customs that seem morally abominable many traditions and institutions throughout to us must be done through changes in social history that have uselessly tried to prevent circumstances. First the economic welfare of people from following their natural motives, and the entire society, and particularly the economic some still do today. While I believe customs and opportunities for women, must improve so pring must not rely motives at work in an environment, as knowledge exclusively upon the man she marries and hi and conditions progress, customs and traditions control over resources. Second, education is should change and possibly be abolished to imperative. Inaccurate beliefs about women and better suit our natural motives. What this female circumcision must be done away with if provides is a position from which it is possible the practice is to be abolished. In general, the to criticize abhorrent customs, institutions, and practice should be abolished, and abolished in moral standards of another culture. this or a similar way, because there exists the

Take, for example, how Arnhart works very real possibility to better fulfill the motives through the case of female circumcision. He that female circumcision is supposed to serve, says that we must consider both the conditions such as the parenting desires of both women and that caused the practice to come about and also men, without also denying other motives, such as women's health and sexual well-being. This case examination has shown that evolutionary theory implies that we reject cultural relativism, and that there are real grounds for criticizing th moral standards of other societies.

The third point to make is that even though evolutionary naturalism cannot tell us exactly how to be morally virtuous, it can tell us where to look. Evolutionary theory tells us that we have a constitution and an environment, and that everything we have to use is from our constitution constantly fed by the environment. Luckily, we still live in the same basic environment for which our constitution is adapted; if the Earth's biosphere is ruined then our genome's chances of reproduction become much slimmer. So where do we look to be a good human? We look to what Nietzsche means by "the Self" - "[i]t rules and is also the Ego's ruler." He goes on to say that there "is more reason in your body than in your best wisdom" and asks "who knows for what purpose your body requires precisely your best wisdom."16 Our moral compass is our Selves! In that case, Nietzsche's point of asking for what purpose your body requires precisely your best wisdom is not unlike the way Dewey rejects moral principles as universal imperatives while he accepts them as useful tools in situations of moral deliberation. Personal aims and goods moral deliberation. Personal aims and goods depend on context, and no universal mandate can fit every situation. Someone might say that your aims, or belief about what you ought to do, should be so and so, and that this ideal would
be your compass. Instead, I would say that we ught to, because to do otherwise would be to contradict some part of my self, remembering Plato, who said through Socrates that "we mus also remember that each one of us will be just and perform his own proper task, when each of the elements within him is performing its proper task." ${ }^{\prime 17}$

Nietzsche asks in The Gay Science "What doe your conscience say?" and then answers with "You shall become the person you are.'"'18 $\mathrm{He}$ again, referring to the idea that our virtue and what is good is built into who we are right now. would even admit this for a serial murdering and raping psychopath. Even this person on the low fringes of morality should become the person they are, keeping in mind that psychopaths are people who appear to be born without any moral collo pychopath to protect childring up the violent psyche the to myself, and society. What we can say now is simply that we are moral and that to be mora definitely means something. While that may no tell us much, it does tell us that there are things it is not. There are infinite moral possibilities because we are free beings, but they are infinite within a limited set.

In conclusion, through a look at both sides fhe evolutionary ethics debate we have found that Darwin's theory is helpful in at least three ways, but also that it is limited in is ability to produce a moral theory. Also, we see that the three contributions, the necessity of daptability, the place of natural motives, and he body's sagacity may have more than minor 
The Ethical Implications of Evolutionary Theory

consequences for our moral outlooks. Still, can person runs as deep as marrow within me. I we elevate moral good above moral evil? Do should not try to contort myself into something I have reason to know why I think of a good that cramps or batters any part of my nature, my person as the morally good one rather than an wants, my motives, my rationality, or anything athletically or an intellectually profound person? else that constitutes what I am unless it is for It may be that morality has become the highest the sake of the whole of me, ony in It may be that me rationing virtue for humans becauseitimproves sociability part of ny self for the sake of ny overall self. We and cooperation, and those are the best aides for should drop any moral theory or practice that survival we have as a species. Maybe I admire is contrary. Although there is no evidence that the great altruism of martyred saints because there exists a single trait shared by all humans, they are the best at what helps us humans the unless by shear coincidence, each of us shares at most. It may be a result of lingering institutional least something with all other humans. Knowing and customary lessons that were necessary for a this, it is possible for all humans to become who certain level of cultural development to occur. It we are and relate, cooperate, and enjoy it, but to might just be the social convention of our time. progress a

e. progress at all we must continue to look within
ef and to be honest with ourselves.

that a good human is a socially virtuous, loving 